\title{
Cutaneous Metastasis of Renal Cell Carcinoma: A Case Report
}

\author{
Lamiae Amaadour, Loubna Atreche, Meryem Azegrar, Zineb Benbrahim, \\ Fatima Zahra EL Mrabet, Samia Arifi, Nawfel Mellas \\ Department of Medical Oncology Hassan II, Faculty of Medicine and Pharmacy Fez, University Hospital of Fez, Fez, Morocco \\ Email: *lamiae.amaadour@gmail.com
}

How to cite this paper: Amaadour, L., Atreche, L., Azegrar, M., Benbrahim, Z., El Mrabet, F.Z., Arifi, S. and Mellas, N. (2017) Cutaneous Metastasis of Renal Cell Carcinoma: A Case Report. Journal of Cancer Therapy, 8, 603-607.

https://doi.org/10.4236/jct.2017.86051

Received: May 6, 2017

Accepted: June 25, 2017

Published: June 28, 2017

Copyright $\odot 2017$ by authors and Scientific Research Publishing Inc. This work is licensed under the Creative Commons Attribution International License (CC BY 4.0).

http://creativecommons.org/licenses/by/4.0/

\begin{abstract}
Renal cell carcinoma (RCC) is known as a highly aggressive malignancy with frequent metastasis that the major sites being lungs, lymphatic ganglions, bones, liver and brain. Cutaneous metastasis is uncommon with only a few reported cases in the literature. We report a case of a women patient aged 49 years old with RCC who underwent nephrectomy and 8 months previously, she consulted the dermatological service due to the development of recent skin lesions that had been diagnosed as cutaneous metastasis of her RCC. The treatment has associated surgical excision and systemic therapy based on sunitinib.
\end{abstract}

\section{Keywords}

Cutaneous Metastasis, Renal Cell Carcinoma, Multikinase Inhibitors

\section{Introduction}

Clear cell renal carcinoma (CCRC) is the most frequent type of renal cell carcinomas, it accounts for approximately $2 \%-3 \%$ of adult cancers [1] [2]. It is the third most common neoplasia of the genitourinary tract, after urinary bladder and prostate tumors.

RCC is known as a highly aggressive tumor with potential metastatic extension in the lymph nodes, bone, opposite kidney, lungs, liver, adrenal glands, brain, bone and other less frequent locations such as the skin. Metastatic CCRC of the skin was very rare and it may be associated with a bad prognosis [3].

We report here in a case of a female patient aged 49 years old with CCRC who has developed cutaneous metastasis.

\section{Case Report}

A 49 years old woman with no past medical history has consulted the hospital 
with right flank pain and macroscopic hematuria. Imaging modalities revealed a right renal tumor. She has undergone a right nephrectomy. Pathological diagnosis was CCRC; overall, it was staged as T3bN0M0, Fuhrman grade 3. Eight months later, she was admitted to the Dermatological Unit for two cutaneous lesions of right arm and left shoulder that were swellings and erythematous with a firm consistency and maximum diameter of $5 \mathrm{~cm}$. Lesions were increased in size over the last two months. During the one month before presentation the patient had weakness with lethargy and she also reported weight loss of about $7 \mathrm{~kg}$.

Surgical treatment was indicated due to rapid growth of lesions. Macroscopic examination showed:

- Swelling right arm: fragment of $5 \times 4 \times 2 \mathrm{~cm}$ without cutaneous coating.

- Swelling left shoulder: fragment of $3.5 \times 3 \times 1.5 \mathrm{~cm}$ without cutaneous coating.

The microscopic histological examination revealed comparable lesions without epidermic coating. The tumor was composed of irregular clear cells with cytological irregularities arranged in acinar structures and solid islets. The mitotic activity in the tumor cells was absent (Figure 1).

Immunohistochemically, the tumor cells were positive for vimentin, and CD10, cytokeratines: pan-CK, EMA indicating epithelial nature of the tumor, but no reaction was found with the other immunohistochemical markers (S100 protein and melanosome (HMB45)).

The histopathological study led to a diagnosis of cutaneous metastasis of CCRC related.

The patient was referred to our department of medical oncology for further treatment. A computed tomography (CT) scan was performed on the thorax abdomen and pelvis that showed a new metastatic lesion in the left para vertebral mass opposite D10 with a maximum diameter of $5.3 \mathrm{~cm}$ also in pancreas.

Blood tests showed normal full blood count, ionogram and liver function.

She underwent palliative treatment with sunitinib a multikinase angiogenesis inhibitor. Sunitinib was administered orally at a dose of $50 \mathrm{mg}$ once daily, in 6-week cycles consisting of 4 weeks of treatment followed by 2-week break. Partial response of disease was observed after 3 months of treatment with acceptable tolerance profile.

\section{Discussion}

Renal cell carcinoma (RCC) represents $20 \%$ to $40 \%$ of all renal tumors. Incidence peak of RCC is between 50 and 70 years of age (mean 66 years) with male sex predominance [4]. Metastatic lesions are discovered in approximately $30 \%$ of patients at the time of diagnosis. The frequent sites of metastases are as follows: lungs (75\%), local lymph nodes (65\%), bones (40\%), liver (40\%), adrenal gland and brain (3\%) [5]. However, metastases from CCRC to the skin are uncommon with only few case reports in literature. Most recurrences happen in the first 3 years and about $20 \%-50 \%$ of patients with CCRC can develop metastasis after nephrectomy [6] [7]. Therefore the development of skin metastases occurs 


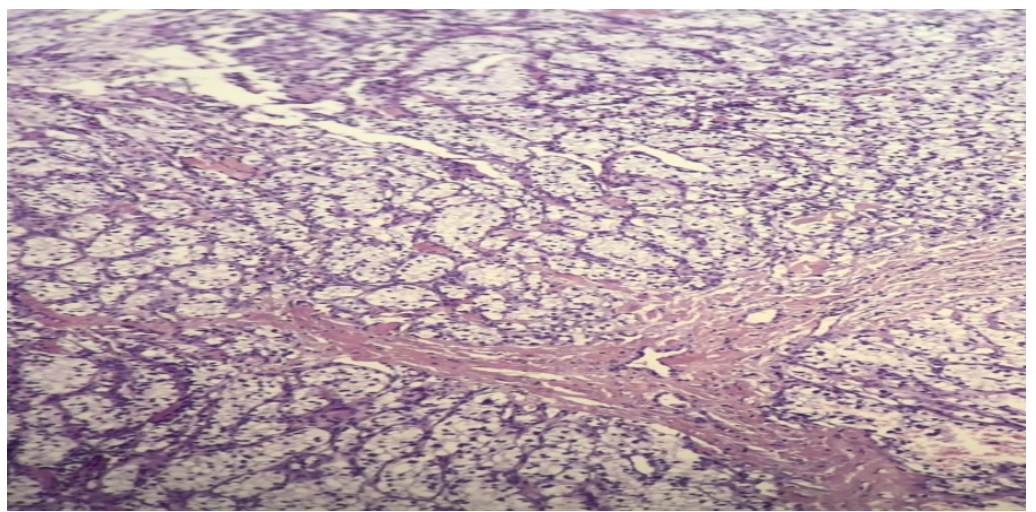

(a)

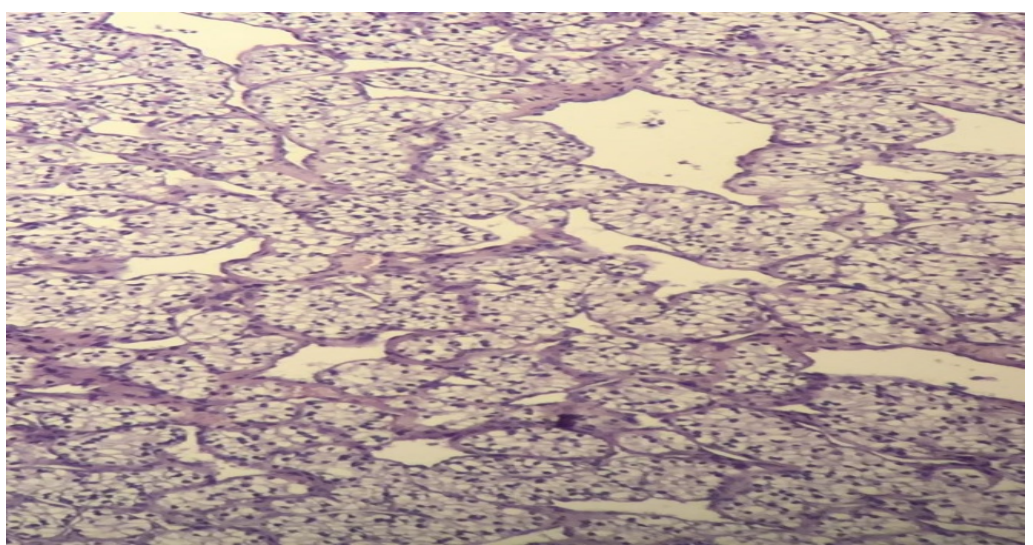

(b)

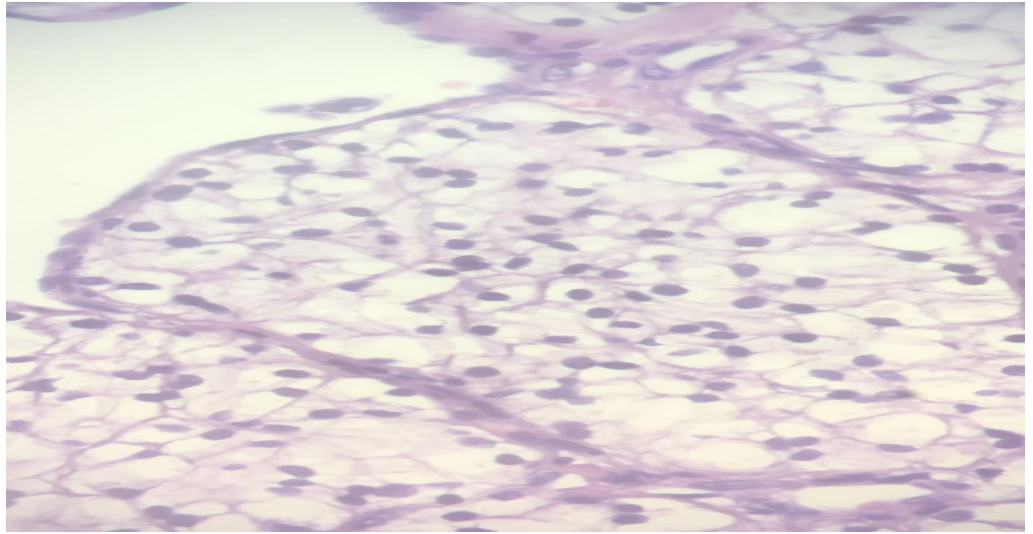

(c)

Figure 1. (a) Irregular clear cells with cytological irregularities ( $\mathrm{H} \& \mathrm{E} \times 100)$; (b) Irregular clear cells arranged in acinar structures and solid islets (H \& E $\times 200)$; (c) Irregular clear cells arranged in acinar structures and solid islets $\mathrm{H} \& \mathrm{E} \times 400$.

within six months to five years of the initial diagnosis and after nefrectomy [8]. The most common primary tumors of coutaneous metastasis are breast, colon and lung cancer. The reported incidence of cutaneous spread from primary urologic malignancies is very rare. CCRC accounts for $6.8 \%$ of cutaneous metastases [5]. The most affected sites are the chest and abdomen.

Renal metastatic cutaneous lesions are frequently single that grow rapidly [8]. The clinical appearance is that the intra- or subcutaneous plaque like, or nodu- 
lar, red-to-purple in color [9]. They are usually very vascular hemorrhagic and pulsatile [5].

Regarding the histopathology, metastatic cutaneous lesions may have a similar appearance to the primary lesion; however, the tumor cells are large, with abundant cytoplasm, round-to-oval nuclei, and evident nucleolus [5].

The tissue cells can form a different structure: glandular, acinar, or papillary with mild lymphocytic inflammatory infiltrate and abundant capillary formation [8]. Immunohistochemically, the positive results with cytokeratins vimentin and EMA suggest skin metastases of renal origin [7].

Differential diagnosis is necessary to rule out other cutaneous tumors such: melanoma sebaceous carcinoma, sweat gland tumor, Kaposi sarcoma, angiosarcoma and sweat gland tumor [10].

However, the treatment is palliative and limited: local excision of the skin lesions can often provides little benefit, due to disseminated metastatic disease. Radiotherapy is an option followed or not by local excision [2]. Metastasectomy and other local radiotherapy can be indicated for selected patients after multidisciplinary review [11].

The International Metastatic CCRC Database Consortium (IMDC) score is used to determinate the score prognosis of metastaic CCRC [12]. Therefore systemic treatment for first-line metastatic RCC is based on multikinase inhibitors (TKIs) that have shown a significant, increase in the possibilities of survival compared to other medical therapies (Interferon or Interleukins). Sunitinib and pazopanib are currently the most commonly used treatments for patients with good or intermediate prognosis [12].

In poor prognosis patients, the recommendation to use temsirolimus or TKIs is not clear and the best supportive care may be an option treatment for the same patient [12].

Once the patient presents with cutaneous metastases the prognosis is poor. The survival ranged from 10.2 months to 22 months and the mean 5-year survival rate of patients with a single cutaneous metastasis of RCC is $13 \%$ to $50 \%$ [7], however if there is multiple lesions the rate do not exceed $8 \%$ [5].

Nonetheless, despite the known worse prognosis of this malignancy, our patient is still alive 10 months later of treatment.

\section{Conclusion}

Metastasis frequently occurs in RCC, with the uncommon skin site, and can imitate other dermatological diseases. It is also associated with poor prognosis. The development of this cutaneous metastasis worsens the clinical prognosis and reduces life expectancy. The new targeted therapy used in the treatment of metastatic RCC, especially cutaneous metastasis may ameliore the prognosis.

\section{Acknowledgements}

The authors declare that they have no competing interests. 


\section{References}

[1] Fernández, R.E., Ponce, D.-R.J.L., Novas, C.S., Lancina, M.A. and González, M.M. (2005) Cutaneous Metastasis of a Renal Carcinoma: Case Report and Review. Archivos Españoles de Urología, 8, 247-250.

[2] Ather, M.H., Masood, N. and Siddiqui, T. (2010) Current Management of Advanced and Metastatic Renal Cell Carcinoma. Urology Journal, 7, 1-9.

[3] Weiss, L., Harlos, J.P., Torhorst, J., et al. (1988) Metastatic Patterns of Renal Carcinoma: An Analysis of 687 Necropsies. Journal of Cancer Research and Clinical Oncology, 114, 605-612. https://doi.org/10.1007/BF00398185

[4] Paula, T.A., Silva, P.S.L. and Berriel, L.G.S. (2010) Renal Cell Carcinoma with Cutaneous Metastasis: Case Report. Jornal Brasileiro de Nefrologia, 32, 213-215. https://doi.org/10.1590/S0101-28002010000200010

[5] Smyth, L.G., Rowan, G.C. and David, M.Q. (2010) Renal Cell Carcinoma Presenting as an Ominous Metachronous Scalp Metastasis. Canadian Urological Association Journal, 4, E64-E66. https://doi.org/10.5489/cuaj.859

[6] Flamigan, R.C., Campbell, S.C., Clark, J.I. and Picken M.M. (2003) Metastatic Renal Cell Carcinoma. Current Treatment Options in Oncology, 4, 385-390. https://doi.org/10.1007/s11864-003-0039-2

[7] Tadashi, T. (2012) Cutaneous Metastasis of Renal Cell Carcinoma: A Report of Two Cases. International Journal of Clinical and Experimental Pathology, 5,175-178.

[8] Arrabal-Polo, M.A., Arias-Santiago, S.A., Aneiros-Fernandez, J., Burkhardt-Perez, P., Arrabal-Martin, M. and Naranjo-Sintes, R. (2009) Cutaneous Metastases in Renal Cell Carcinoma: A Case Report. Cases Journal, 2, 7948.

https://doi.org/10.4076/1757-1626-2-7948

[9] Amano, Y., Ohni, S., Ishige, T., Homma, T., Yamada, T., Nishimori, N. and Nemoto, N. (2015) A Case of Cutaneous Metastasis from a Clear Cell Renal Cell Carcinoma with an Eosinophilic Cell Component to the Submandibular Region. Journal of Nihon University Medical Association, 74, 73-77. https://doi.org/10.4264/numa.74.73

[10] Mahmoudi, H.R., Kamyab, K. and Daneshpazhooh, M. (2012) Cutaneous Metastasis of Renal Cell Carcinoma: A Case Report. Dermatology Online Journal, 18, 12.

[11] Escudier, B., Porta, C., Schmidinger, M., Algaba, F., Patard, J.J., Khoo, V., Eisen, T. and Horwich, A. (2016) Renal Cell Carcinoma: ESMO Clinical Practice Guidelines for Diagnosis, Treatment and Follow-Up. Ann Oncology, 27, v58-v68. https://doi.org/10.1093/annonc/mdw328

[12] Motzer, R.J., Hutson, T.E., Cella, D., et al. (2013) Pazopanib versus Sunitinib in Metastatic Renal Cell Carcinoma. The New England Journal of Medicine, 369, 722-731. https://doi.org/10.1056/NEJMoa1303989 
Submit or recommend next manuscript to SCIRP and we will provide best service for you:

Accepting pre-submission inquiries through Email, Facebook, LinkedIn, Twitter, etc. A wide selection of journals (inclusive of 9 subjects, more than 200 journals)

Providing 24-hour high-quality service

User-friendly online submission system

Fair and swift peer-review system

Efficient typesetting and proofreading procedure

Display of the result of downloads and visits, as well as the number of cited articles Maximum dissemination of your research work

Submit your manuscript at: http://papersubmission.scirp.org/

Or contact jet@scirp.org 